\title{
PENDAMPINGAN PASTORAL HOLISTIK: SEBUAH USULAN KONSEPTUAL PEMBINAAN WARGA GEREJA
}

\author{
Fibry Jati Nugroho \\ Sekolah Tinggi Teologi Sangkakala \\ Getasan, Kab. Semarang \\ E-mail: fibryjatinugroho@gmail.com
}

\begin{abstract}
Fibry Jati Nugroho, Pastoral Assistance Holistic: A Proposed Conceptual Development Residents Church. A strong church is formed of a strong congregation. Strong congregation obtained from the pastoral care that actively touches the whole life of the churches. The Church should strive to develop a holistic pastoral care to the congregation. Various programs designed to be used to achieve a holistic pastoral care. Multiculture congregation accompanied by multiproblem, requiring pastoral agents set the strategy and create a model to be able to provide a holistic pastoral care services to the citizens of his church. The concept of holistic pastoral care of Howard Clinebell and Totok Wiryasaputra will help create a framework to analyze the development of church people holistically. The theoretical framework will be integrated with pastoral models developed by David Yonggi Cho's Yoido Full Gospel Church. The concept and model of pastoral care holistic support each other as well as a "scalpel" of pastoral care that is geared towards the empowerment of the laity effectiveness and small groups methods.
\end{abstract}

Keyword: Holistic Pastoral, Small Group

ABSTRAK: Fibry Jati Nugroho,Pendampingan Pastoral Holistik:Sebuah Usulan Konseptual Pembinaan Warga Gereja. Gereja yang kuat terbentuk dari jemaat yang kuat. Jemaat yang kuat didapat dari pendampingan pastoral yang secara aktif menyentuh keseluruhan kehidupan warga gerejanya. Gereja perlu berusaha mengembangkan pendampingan pastoral holistik kepada jemaatnya. Berbagai program yang dirancang digunakan untuk mencapai sebuah pendampingan pastoral holistik. Jemaat yang multikultur disertai dengan multiproblem, mengharuskan para pelaku pastoral mengatur strategi dan menyusun model untuk dapat memberikan pelayanan pendampingan pastoral holistik kepada warga gerejanya. Konsep pendampingan pastoral holistik dari Howard Clinebell dan Totok Wiryasaputra akan membantu menganalisis dalam kerangka membuat pembinaan warga gereja secara holistik. Kerangka teoretis tersebut akan dipadukan dengan model pastoral yang dikembangkan oleh David Yonggi Cho di Yoido Full Gospel Church. Konsep dan model pendampingan pastoral holistik saling menopang serta menjadi "pisau bedah" dari pendampingan pastoral yang bermuara kepada efektifitas pemberdayaan kaum awam dan metode kelompok kecil.

Kata kunci: Pastoral holistik, Kelompok Kecil.

\section{PENDAHULUAN}

Banyak hal di dalam kehidupan manusia, yang memunculkan kompleksitas permasalahan hidup. Baik permasalahan dengan diri sendiri maupun dengan lingkungannya. Tidak dapat dipungkiri setiap orang mempunyai permasalahan yang berbeda-beda di dalam hidupnya. Setiap permasalahan memerlukan solusi, baik melalui diri sendiri, maupun pendampingan dari orang lain. Pendampingan dari orang lain dapat membantu menguraikan kompleksitas permasalahan di dalam kehidupannya. Adapun manusia sendiri mempunyai empat aspek yang mempengaruhi kehidupannya, yaitu fisik, mental, sosial, dan spiritual.
Keempat aspek tersebut sangat berpengaruh dalam permasalahan hidup manusia. Apabila dikaitkan dengan kehidupan bergereja, pendampingan pastoral merupakan sebuah upaya dalam rangka menolong sesama manusia yang mengalami berbagai permasalahan hidup.

Istilah pendampingan pastoral tidak asing lagi dalam kehidupan bergereja. Tidak jarang banyak gereja yang mulai memasukkan pendampingan pastoral sebagai program gereja. Akan tetapi, seringkali perhatian gereja hanya terfokus dalam segi spiritualnya saja, dan mengesampingkan aspek lain dalam hidup manusia. Apabila seseorang datang meminta sa- 
ran atau solusi atas masalahnya, pihak gereja cenderung hanya memberi solusi berdasarkan analisis aspek kerohanian saja. Jika gereja tidak memperhatikan keempat aspek manusia tersebut secara menyeluruh, maka pendampingan yang dilakukan tidak dapat menyentuh kehidupan secara utuh. Jemaat yang sangat banyak memerlukan perhatian ekstra dari pihak gereja. Kuantitas dan kompleksitas dari manusia menuntut kerja keras dari pendeta jemaat. Oleh sebab itu, diperlukan formulasi khusus dalam mengadakan pendampingan pastoral holistik di dalam proses pembinaan warga gereja.

Membincang perihal pembinaan warga gereja, ada banyak hal yang dapat menjadi bahan diskusi. Kompleksitas di dalam kehidupan jemaat sangat menarik untuk dikaji dan ditelisik dengan lebih mendalam. Permasalahan di dalam jemaat saling berkelindan, sehingga memerlukan perhatian yang serius untuk membina jemaat yang telah dipercayakan Tuhan kepada gereja-Nya. Konsep pembinaan holistik merupakan sebuah alternatif usulan konkret untuk dapat dijadikan sebuah model pembinaan warga gereja. Konsep holistik diperlukan untuk menyentuh seluruh kebutuhan dari jemaat, bukan hanya kebutuhan sektariannya saja.

Dalam kajian ini, penulis berusaha memaparkan alternatif usulan dalam rangka pendampingan pastoral holistik, dalam kerangka pembinaan warga gereja. Mengingat kuantitas jemaat di dalam gereja yang multikultur dan multi problem, muncul pertanyaan apakah pendampingan pastoral yang dilakukan mengacu kepada keutuhan manusia yang terdiri dari fisik, mental, spiritual, dan sosial? Bagaimanakah konsep model pastoral dalam melakukan pendampingan pastoral kepada seluruh jemaatnya secara holistik? Permasalahan inilah yang akan diperbincangkan dalam tulisan ini.

\section{METODE}

Pada penelitian ini penulis menggunakan metode deskriptif analisis dengan pendekatan kualitatif. Whitney menyatakan bahwa metode penelitian des- kriptif adalah pencarian fakta dengan interpretasi yang tepat. Penelitian deskriptif mempelajari masalah-masalah dalam masyarakat, tata cara yang berlaku dalam masyarakat, situasi tertentu termasuk tentang hubungan, kegiatan-kegiatan, sikap-sikap, pandangan-pandangan, proses-proses yang sedang berlangsung dan pengaruh-pengaruh dari suatu fenomena. ${ }^{1}$ Fenomena yang berusaha ditelisik dalam tulisan ini adalah kerangka konseptual pendampingan pastoral holisik dalam kaitannya dengan pembinaan warga gereja.

Beberapa sumber yang menjadi acuan utama dalam tulisan ini adalah pandangan konseptual dari Totok Wiryasaputra dan Clinebell. Dari sisi praksis, penulis mengajak menilik seklumit tentang pendampingan pastoral yang dikembangkan oleh gereja di Korea yang digembalakan oleh Paul Yongi Cho. Clinebell merupakan salah satu pakar dari teori holistik. Pandangan konseptual dari Clinebell akan memberi arahan tentang pastoral holistik. Konteks dan latar Indonesia akan terwakili dengan salah satu tokoh pastoral Indonesia yaitu Wiryasaputra. Pengalamannya dalam pendampingan jemaat di Indonesia, akan membawa sebuah kerangka tentang konsep pendampingan holistik di Indonesia. Dari sisi praksis, tokoh Asia yang mendunia, yaitu Paul Yonggi Cho akan dipakai sebagai sebuah cerminan untuk menyajikan pendampingan pastoral yang holistik dari konteks Asia. Dua tokoh konseptual dan praktisi dari Asia akan dikolaborasikan untuk dapat ditarik menjadi sebuah usulan konseptual pendampingan pastoral di Indonesia. Beberapa sajian konsep tersebut akan disajikan secara deskriptif dalam tulisan ini. Dari sajian konsep praksis tersebut, kiranya dapat memberikan alternatif usulan dalam mengembangkan pastoral holistik, dalam kerangka pembinaan warga gereja.

\section{HASIL DAN PEMBAHASAN}

\footnotetext{
${ }^{1}$ Moh.Nasir, Metode Penelitian (Bogor: Ghalia
} Indonesia, 2005),54. 


\section{Tinjauan Umum}

\section{Konsep Jemaat}

Gereja terbentuk dari kumpulan orangorang yang datang untuk beribadah kepada Tuhan. Orang yang sehati untuk menghadap Tuhan akan bersama-sama berkumpul dan membentuk komunitas tersendiri. Komunitas tersebut akan saling berinteraksi satu dengan lainnya. Dalam konteks kekristenan, kumpulan tersebut akan membentuk sebuah gereja. Orang-orang yang berkumpul dan bersekutu dalam sebuah gereja sering disebut dengan jemaat atau warga gereja.

Secara etimologis, kata jemaat adalah istilah serapan dari bahasa Arab. Kamus Besar Bahasa Indonesia memberi definisi kata jemaat adalah himpunan umat. ${ }^{2}$ Dalam Perjanjian Baru (PB), jemaat dituliskan dengan kata ekklesia (Bahasa Yunani). Kata tersebut merupakan bentukan dari kata depan ek (keluar dari) dan kata kerja kaleo (panggil). Dari hal tersebut didapat makna harafiahnya adalah orangorang yang dipanggil keluar, yaitu keluar dari kegelapan dunia kafir masuk ke dalam terang kehadiran Allah. Secara umum, kata ekklesia dalam bahasa aslinya mempunyai arti pertemuan. Namun, dalam kitab-kitab Perjanjian Baru istilah ekklesia digunakan dalam konteks Kristen yang khusus. Dalam konteks pemakaiannya sebagai istilah Kristen, ekklesia lebih merujuk pada: (1) Hal bersekutu, yakni persekutuan/ pertemuan orang-orang percaya; (2) Hal pemilikan, yaitu: mereka yang menjadi milik Tuhan.

Persekutuan orang percaya tersebut terpola dalam sebuah gereja. Pada perkembangannya, istilah jemaat menjadi populer dipakai di kalangan kekristenan. Berdasarkan fungsinya, jemaat mempunyai tempat yang penting di dalam kerangka pendampingan pastoral. Jemaat bukan saja sebagai obyek, tetapi juga menjadi subyek dari pelayanan pendampingan pastoral. Thurnesysen seorang tokoh teologi

\section{s.v. "jemaat"}

pastoral memberi penjelasan bahwa secara prinsipal percakapan pastoral berlangsung dalam ranah jemaat. Setiap percakapan pastoral harus memimpin jemaat menuju kepada pengenalan akan Tuhan. Pelayanan pastoral dilakukan melalui pemberitaan firman Allah, pengudusan, pembenaran dan persekutuan. Semua kegiatan pastoral tersebut terintegrasi dan berorientasi pada kerajaan Allah.

Di sisi lain, teolog Lutheran yaitu Trillhaas berpendapat bahwa pelayanan pastoral adalah pelayanan jemaat sebagai tubuh Kristus. Paradigma ini didasarkan dari landasan Kristus sebagai kepala dan jemaat adalah anggota tubuhnya. Pelayanan pastoral sendiri merupakan sebuah pemeliharaan jiwa dari manusia kepada manusia. Bentuk pemeliharaan jiwa ini termaktub di dalam terpeliharanya relasi antar jemaat, yang berujung pada sikap saling menolong dalam kehidupannya sehari-hari.

Berbeda dengan teolog yang lain, kaum teolog pastoral Amerika tidak menyebut pastoral sebagai bagian dari tujuan pelayanan gereja. Akan tetapi, paradigma yang berkembang adalah pelayanan pastoral merupakan sebuah usaha membantu manusia dalam mengatasi berbagai macam problemanya. $\mathrm{Pa}$ ra teolog pastoral berpendapat bila seseorang telah terbantu problemanya, maka ia akan menjadi anggota gereja yang baik dan bertanggung jawab. Oleh sebab itu, problema diantara jemaat harus diatasi dengan baik agar dapat menghasilkan warga gereja yang baik pula.

Beberapa pandangan tokoh tesebut di atas, tampak bahwa jemaat mendapatkan tempat penting dalam sebuah gereja. Gereja yang kuat terbentuk dari jemaat yang kuat. Untuk membentuk jemaat yang kuat, diperlukan pendampingan pastoral holistik yang dikembangkan oleh gereja. Jemaat yang mendapatkan perhatian secara holistik dari pelaku pastoral akan berkontribusi pula dalam perkembangan gereja. Oleh sebab itu, pendampingan pastoral holistik mendapat tempat yang vital dalam kehidupan sebuah gereja. 
Kata holistik sendiri acapkali dihubungkan dengan istilah kesehatan. Apabila dikaitan dengan istilah kesehatan, keadaan yang dianggap sehat secara holistik adalah sehat secara menyeluruh. Holistik sendiri mencakup aspek fisik, mental, spiritual dan sosial. Keempat aspek tersebut tidak bisa dipisah-pisahkan, mereka memiliki keterkaitan yang erat-tak terpisahkan. ${ }^{3}$ Aspek-aspek inilah yang merupakan bentuk dari keutuhan dari manusia.

\section{Dasar Teologis Pendampingan Pastoral Holistik}

Dari berbagai pandangan perihal konsep holistik, secara teologis dimensi holistik telah tampak melalui istilah shalom dalam perjanjian lama. Istilah ini mempunyai arti yang sangat luas berkenaan dengan keadaan sejahtera pada seseorang. Secara literal, kata shalom mempunyai arti sehat, aman, dan sejahtera. Bila menilik akar kata Ibrani, kata shalom berasal dari kata 'sh-l-m'. Menurut Evans, ada tiga konsep dalam kata shalom, yaitu "totality (the adjective shalem is translated 'whole'), well-being, and harmony". Konsep tersebut merupakan cakupan dari kata shalom, yang menyangkut keseluruhan aspek hidup manusia secara total, tetapi tetap selaras dengan ciptaan Tuhan, baik sesama dan alam sekitar. Shalom menunjuk pada waktu yang sama secara keseluruhan, berdasarkan fakta yang utuh.

Aspek holistik lain pada manusia tampak dalam kisah penciptaan yang tertuang dalam Kejadian pasal 1. Pada kisah tersebut tampak dengan jelas bahwa Tuhan menciptakan manusia dengan unik dan disertai dengan berbagai macam aspek kemanusiaannya. Wirsyasaputra menuliskan bahwa "The biblical worldview is theocentric-anthropocentric. In creating human existence, God used a special act, special intervention (Genesis 1:27 and 2:7). ${ }^{5}$ Dari

\footnotetext{
${ }^{3}$ Mesakh Krisetya, Diktat Teologi Pastoral, (Salatiga: Fakultas Teologi UKSW, 2006), 29

${ }^{4}$ Evans, C.F., "Peace"A Theological Word Book of the Bible, (New York: Abingdon,1950), 165.

${ }^{5}$ Totok Sumartho Wiryasaputra, The Social Responsibility Of Pastoral Care Ministry At The Hospital
}

sejak semula, manusia dibentuk sebagai makhluk yang spesial dengan beragam aspek di dalam dirinya.

Pada kitab Kejadian terutama dalam kisah penciptaan, manusia merupakan tokoh sentral yang ditonjolkan. Nats dalam Kejadian 2:7, memberi kesaksian berkenaan dengan substansi dari manusia. Kesatuan dari manusia itu terdiri dari pneuma-psikologi-somatis. Menurut Eka Darma Putera, susunan kesatuan manusia itu adalah (1) Manusia adalah debu (adama) atau aspek fisik. Ia adalah tubuh, materi. Allah yang membuat itu! Allah juga amat memperhatikan kebutuhan fisik manusia (Kej. 2:9); (2) Manusia adalah jiwa (psykhe) atau aspek mental. Mempunyai kebutuhan-kebutuhan kejiwaan dan Allah juga amat memperhatikan kebutuhan kejiwaan manusia. Ia tidakmembiarkan manusia kesepian (2:18). Manusia diberi kebebasan $(2: 16)$. Manusia dikaruniai kepercayaan dan tanggung jawab (2:15); (3) Manusia adalah roh atau disebut dengan aspek spiritual. Allah memberi 'nafas hidup', bahkan menghembuskan itudari 'nafas hidup' Allah sendiri (2:7). Inilah yang membuat hubungan yang amat istimewa antara manusia dengan Allah. "Engkau telah membuatnya hampir sama seperti Allah, dan telah memahkotainya dengan kemuliaan dan hormat" (Maz 8:6). Manusia diciptakan sebagai 'gambar Allah' sendiri $(1: 26,27)$. Artinya, ia mempunyai harkat dan martabat yang amat mulia. Pelayanan holistik memperhatikan semua dimensi ini: keterbatasan tetapi sekaligus juga martabat manusia. ${ }^{6}$

\section{Konsep Wiryasaputra}

Konsep manusia sebagai makhluk holistik tidak dapat dikesampingkan. Berbagai gejala yang terjadi dalam hidup manusia, baik berupa permasalahan maupun penyakit selalu berhubungan dengan

Setting In Indonesia, Master Thesis, Columbia Theological Seminary, 14

${ }^{6}$ Holistik Life Diunduh dari http://www.fica.org/ ficalist/fica/live/holistik, Selasa, 23 Agustus 2016, 15.15 WIB 
beberapa aspek dalam hidup manusia. Wiryasaputra mencoba memformulasikan keberagaman aspek hidup manusia ke dalam empat hal, yaitu:

1. Aspek fisik: aspek ini berkaitan dengan bagian yang tampak dari hidup manusia. Aspek fisik mengarah kepada apa yang dapat disentuh, dilihat dan diraba. Hal ini berkaitan pula dengan kebutuhan jasmani dari manusia. Bila dirinci maka aspek ini meliputi: pangan, papan, sandang, kebersihan tubuh, keutuhan tubuh, pelayanan medis, sistemik tubuh atau metabolisme tubuh, gerak badan, rileks-istirahat, dan lingkungan alam sekitar.

2. Aspek Mental: aspek ini berkaitan dengan pikiran, emosi dan kepribadian manusia. Hal ini juga menyangkut dengan cipta, rasa, karsa, motivasi, dan integrasi diri manusia. Bagian ini meliputi pula pada hubungan seseorang dengan bagian dalam dirinya (batin, jiwa). Adapun rincian dalam aspek ini adalah kasih sayang baik memberi atau menerima, kedewasaan emosional, integertas diri, kemampuan intelektual, kreativitas diri, ekspresi diri, kebanggaan diri, rasa keindahan atau estetika, identitas seksualitas, dan perasaan aman serta nyaman.

3. Aspek Spiritual: bagian ini menyangkut tentang hubungan dengan jati diri manusia. Manusia secara khusus dapat berhubungan dengan sang pencipta sejati. Aspek ini mengacu kepada sesuatu yang berada jauh di luar jangkauannya. Pada bagian ini memungkinkan manusia untuk berhubungan dengan dunia lain (gaib). Bila dirinci, maka bagian ini meliputi, doa, kontemplasi, rasa manunggal bersekutu dengan sang mahakuasa, pengharapan akan masa depan, visi hidup, rasa bersyukur, identifikasi komunitas, relasi dengan komunitas percaya, nilai - nilai mulia, dan kesalehan.

4. Aspek sosial : Aspek ini berkaitan dengan keberadaan manusia yang tidak mungkin berdiri sendiri. Manusia harus dilihat dalam hubungannya dengan pihak luar secara horizontal, yakni dunia sekelilingnya. Manusia dalam kaitannya dengan aspek sosial tidak dapat terlepas dari relasi dan interaksi. Aspek sosial meliputi: kondisi ekonomi yang memungkinkan seseorang hidup layak, kemampuan keuangan dan pe- kerjaan, kualitas pendidikan untuk menopang kehidupan, kondisi perpolitikkan yang memungkinkan seorang bertumbuh guna mengekspresikan diri, identifikasi kultural, kondisi adat istiadat, hubungan dengan anggota keluarga, hubungan dengan teman, hubungan dengan lingkungan sosial, serta keterlibatan dalam aktivitas lingkungan. ${ }^{7}$

Keempat aspek tersebut di atas saling berkaitan satu dengan yang lain, serta saling mempengaruhi secara sistemik dan sinergik membentuk eksistensi manusia sebagai keutuhan dan bertumbuh kepada aktualiasasi dirinya. Gambaran dari kesatuan aspek tersebut tampak dalam diagram berikut:

\section{Gambar 1. Diagram Holistik Wiryasaputra}

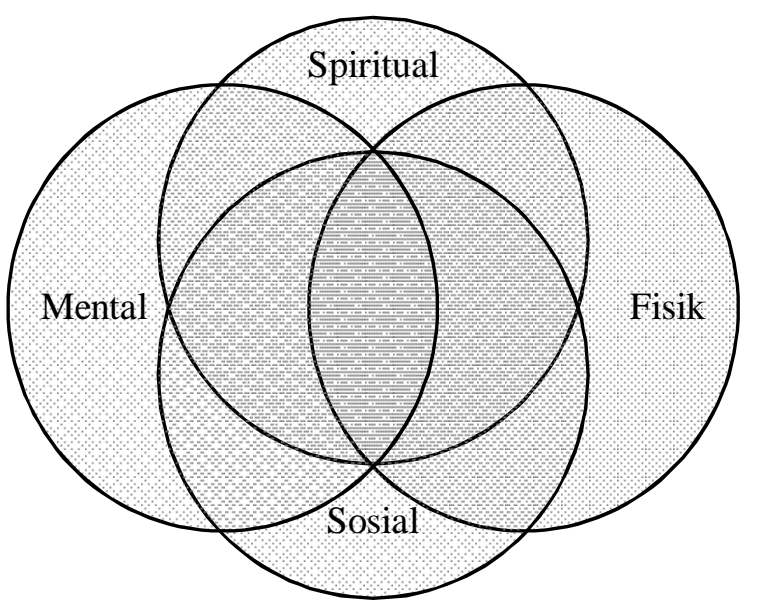

Pada keempat aspek tersebut ada beberapa bagian yang saling berimpitan. Gambar di atas menunjukkan bahwa aspek-aspek hidup manusia dapat dibedakan, tetapi tidak dapat dipisahkan. Keempat aspek itu saling berkaitan dan mempengaruhi. ${ }^{8}$ Oleh sebab itu, dalam melakukan pendampingan, hendaknya melibatkan berbagai pihak guna menangani manusia secara holistik dengan segala persoalannya yang multidimensional. ${ }^{9}$

Pendampingan pastoral merupakan cara dalam melakukan pendampingan kepada seseorang. Namun, acapkali masyarakat mempunyai konotasi negatif ketika melihat seseorang didampingi oleh

\footnotetext{
${ }^{7}$ Ibid, 39.

${ }^{8}$ Ibid, 41.

${ }^{9}$ Ibid, 44
} 
seorang konselor. Asumsi ini muncul disebabkan karena orang yang sedang didampingi terlibat suatu masalah yang besar, atau sedang dalam keadaan berdosa. Asumsi lain yang berkembang di masyarakat yaitu orang merasa takut didampingi oleh seorang konselor, karena mereka takut dihakimi oleh konselor tersebut. Bila menilik kembali arti dari pendampingan, maka orang yang didampingi bukanlah merupakan obyek, melainkan berada sejajar dengan konselor dan sebagai sesama yang wajib untuk ditolong secara utuh (holistik).

\section{Konsep Clinebell}

Dunia gerejawi mengenal pendampingan pastoral hanya sebagai tugas pendeta. Pendeta dijadikan sebagai orang yang bertanggung jawab dalam penggembalaan. Seiring dengan perkembangan zaman, permasalahan manusia yang semakin kompleks dan pertumbuhan jemaat yang semakin meningkat, maka paradigma tentang pendampingan pun semakin berkembang agar dapat menjawab tantangan dan kebutuhan jemaat. Clinebell memberi pernyataan, bahwa pendampingan pastoral mencakup pelayanan yang saling menyembuhkan dan menumbuhkan di dalam suatu jemaat dan komunitasnya sepanjang perjalanan hidup mereka. ${ }^{10}$ Senada dengan hal ini, Janse van Rensburg berpendapat bahwa This means that pastoral care and the other aspects of ministry, including Christian charity, evangelism and actions of empowerment should be seen as aspects of the same action, being, as the expression goes, two sides of the same coin. ${ }^{11}$ Dari pendapat kedua tokoh tersebut semakin memperkuat bahwa diperlukan orang lain yang membantu pendeta dalam melakukan pendampingan pastoral secara utuh.

${ }^{10}$ Howard Clinebell, Tipe-Tipe Dasar Pendampingan dan Konseling Pastoral, (Yogyakarta: Kanisius, 2002), 32.

${ }^{11}$ Janse van Rensburg, J., 2010, "A holistic approach to pastoral care and poverty," Verbum et Ecclesia 31 (1), Art. \#386, 7 pages. DOI: 10.4102/ ve.v31i1.386,. Education Research Complete, EBSCOhost (accessed March 11, 2011).
Demi mewujudkan pendampingan secara utuh, maka diperlukan sebuah paradigma yang menjadi landasan dalam pergerakannya. Van Beek mengemukakan beberapa anggapan tentang paradigma pendampingan pastoral yang berkembang di Indonesia, yaitu :

1. Pembinaan, yaitu tugas membentuk watak seseorang dan mendidik mereka untuk menjadi murid Kristus yang baik.

2. Pemberitaan firman Allah, yakni pada setiap pertemuan membahas firman Allah.

3. Pelayanan sakramen, merupakan bentuk perhatian kepada setiap jemaat.

4. Pelayanan penyembuhan, terutama di kalangan karismatik merupakan pelayanan rohani yang berdampak pada penyembuhan fisik.

5. Pelayanan kepada masyarakat, yaitu pelayanan sosial dan pelayanan berjuang melawan ketidakadilan.

6. Penyampai interaksi antara Allah dan manusia, ini merupakan sebuah penantian suatu penyataan dari Allah.

7. Pelayanan konseling pastoral, merupakan pelayanan yang memakai teknik-teknik khusus yang dipinjam dari ilmu-ilmu manusia, khususnya psikologi. ${ }^{12}$

Berbeda dengan van Beek, Clebsch dan Jaekle memformulasikan fungsi pendampingan dalam empat bagian $^{13}$, yaitu: (1) Menyembuhkan adalah fungsi pastoral yang bertujuan untuk mengatasi beberapa kerusakan dengan cara mengembalikan orang itu pada suatu keutuhan, dan menuntun dia ke arah yang lebih baik daripada kondisi sebelumnya; (2) Menopang yaitu menolong orang lain yang "terluka" untuk bertahan dan melewati suatu keadaan, yang di dalamnya mengandung unsur pemulihan kepada kondisi semula atau penyembuhan dari penyakitnya tidak mungkin atau tipis kemungkinannya; (3) Membimbing berarti membantu orang-orang yang kebingungan untuk menentukan pilihan-pilihan yang pas-

${ }^{12}$ Aart Van Beek, Pendampingan Pastoral (Jakarta: BPK Gunung Mulia, 2003), 11.

${ }^{13}$ William A. Clebsch \& Charles R. Jaekle, Pastoral Care in Historical Perspective (USA: Aronson, 1964). 
ti diantara berbagai pikiran dan tindakan alternatif, jika pilihan-pilihan tersebut dipandang sebagai yang mempengaruhi keadaan jiwanya sekarang dan yang akan datang; (4) Mendamaikan merupakan upaya membangun ulang relasi manusia dengan sesamanya, dan antara manusia dengan Allah.

Seorang tokoh pastoral lain yaitu Clinebell, menambahkan fungsi mengasuh sebagai bentuk pengembangan dan pertumbuhan secara holistis. ${ }^{14}$ Bentuk yang dikemukakan oleh Clinebell banyak dipakai oleh orang yang bergerak di bidang pendampingan untuk menciptakan model pendampingan secara holistik. Clinebell merupakan tokoh konseling pastoral yang gemar mendengungkan pendampingan pastoral holistik. Beberapa tulisannya, Clinebell menyatakan bahwa pendampingan dan konseling pastoral harus menekankan pada pembebasan dan pertumbuhan diri manusia secara menyeluruh. Clinebell menyatakan pemikirannya dalam bukunya yang berjudul Growth Counseling bahwa ada enam dimensi dalam pertumbuhan manusia. Adapun dimensi itu meliputi inner growth enlivening One's Mind, revitalizing one's body, renewing our relationships, growth in relating to the biosphere, growth in relation to organizations and institutions, spiritual growth. ${ }^{15} \mathrm{Cli}-$ nebell berpendapat bahwa keenam dimensi ini yang merupakan dimensi yang harus ditumbuhkan dengan seimbang guna terwujudnya keutuhan dalam diri manusia.

Clinebell menekankan bahwa melalui pendampingan yang dilakukan oleh gereja, jemaat dapat menemukan keutuhan di dalam hidupnya. Oleh sebab itu,

Pendampingan pastoral dan konseling harus bersifat holistik (menyeluruh) artinya berusaha untuk memungkinkan penyembuhan dan pertumbuhan keutuhan manusia dalam dimensinya. Model itu berorientasi pada sistem-sistem, artinya keutuhan orang dilihat dalam keterlibatannya dalam segala hubungan-hubung-

\footnotetext{
${ }^{14}$ van Beek, Pendampingan Pastoral, 12

${ }^{15}$ Howard Clinebell, Growth Counseling (Nashville: Abingdon, 1982), 19.
}

annya yang penting dan saling ketergantungannnya dengan orang-orang, kelompok-kelompok dan institusi-institusi. ${ }^{16}$

Keutuhan tersebut dapat diperoleh, apabila paradigma pendampingan pastoral ini dimengerti pula oleh pendeta. Pendeta merupakan pelatih yang bertanggung jawab untuk memampukan anggota jemaat saling melayani, di samping menjalankan pelayanannya diri sendiri yang unik dan berharga. ${ }^{17}$ Jemaat yang dilatih dan diperlengkapi membuat gereja tersebut hidup, serta dapat memaksimalkan potensi yang ada di dalam jemaat.

Clinebell mengemukakan, bahwa keenam aspek dalam kehidupan manusia tersebut saling terkait satu dengan yang lainnya. Apabila salah satu aspek belum dapat terpenuhi, maka akan berdampak pada laju pertumbuhan hidup seseorang. Pendam-pingan pastoral yang dilakukan gereja dimaksudkan membantu seseorang untuk dapat menemukan keutuhan dalam kehidupan. Oleh sebab itu, penanganan yang dilakukan oleh gereja harus meliputi keenam aspek hidup manusia. Clinebell membuat formulasi dalam bentuk diagram berkenaan dengan peranan gereja dalam melayani jemaatnya.

Gambar 2. Diagram Holistik Clinebell

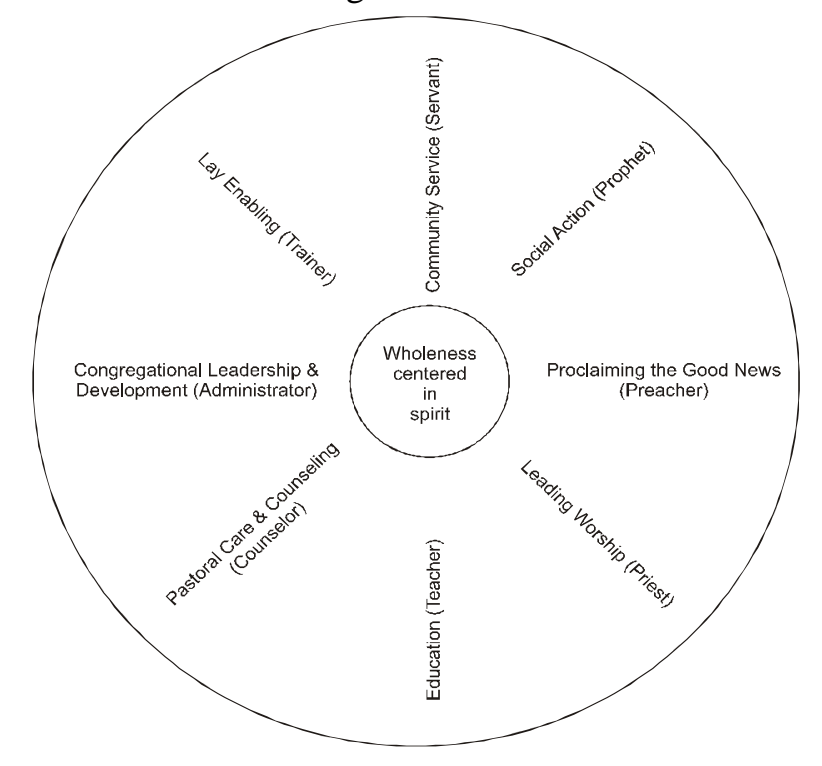

${ }^{16}$ Howard Clinebell, ed. Anne Homes, Tipe-Tipe Dasar Pendampingan dan Konseling Pastoral (Yogyakarta: Kanisius, 2002),33

${ }^{17}$ Ibid. 
Teori Clinebell menyatakan bahwa pendampingan pastoral holistik merupakan tugas dari gereja, yang membawa keutuhan dalam kehidupan manusia. Melalui gambaran dari Clinebell tersebut di atas, tampak bahwa aspek spiritual merupakan kunci dari pertumbuhan kehidupan manusia. Clinebell berpendapat bahwa "Spiritual growth is the key to all human growth. Because human beings are inherently transpersonaland transcendent, there is no way to fullfill oneself except in relationship to the larger spiritual reality". ${ }^{18}$ Dalam hal ini, Clinebell hendak menempatkan agama bukan sebagai lembaga, melainkan sebagai usaha untuk menumbuh kembangkan kehidupan spiritualitasnya. Agama harus kembali kepada fungsi aslinya, yaitu sebagai sarana pengembalian manusia dalam segi spiritualitasnya, agar membuahkan tingkah laku yang sesuai dengan ajarannya. Lewat pengalaman spiritualitas yang mendalam, seseorang akan mampu menjadikan dirinya sejahtera secara utuh.

Wiryasaputra juga merupakan tokoh konseling pastoral yang gemar menyerukan tentang konsep pendampingan pastoral holistik. Pada beberapa tulisan dan pengajarannya, tampak sekali konsistensi tentang konsep manusia sebagai makhluk holistik. Ia berpandangan bahwa permasalahan manusia tidak dapat diselesaikan secara parsialistik, tetapi harus dilihat secara keseluruhan hidup manusia. Sebagai contoh pandangan parsialistik ini misalnya seorang hanya dilihat aspek fisik tanpa memperhatikan aspek kehidupan yang lain seperti mental, spiritual dan sosial. Terlebih lagi, manusia dianggap sama seperti mesin secara mekanis yang tidak memiliki kemampuan inheren, kepercayaan, nilai, motivasi, sejarah, hubungan dan interaksi dengan lingkungannya. ${ }^{19}$ Oleh sebab itu, dalam melakukan pendampingan pastoral kepada seseorang harus tetap mengacu kepada keutuhan dari manusia. Mesach Krisetya mempertegas dengan memamparkan suatu model pen-

\footnotetext{
${ }^{18}$ Clinebell, Growth Counseling, 101.

${ }^{19}$ Wiryasaputra, Ready to Care, 36.
}

dampingan pastoral holistik melalui perkunjungan pastoral. ${ }^{20}$ Model ini merupakan langkah nyata untuk dapat mengerti kebutuhan secara utuh dari keseluruhan kehidupannya, sehingga lebih tepat dalam melakukan langkah praktis pendampingannya.

Gereja yang semakin besar jumlah jemaatnya memerlukan perhatian khusus dalam hal pendampingan pastoral. Fenomena gereja pada masa kini cenderung mengarah ke model megachurch. Model gereja semacam ini memerlukan suatu program yang dapat dikembangkan secara signifikan. Dalam rangka memberikan pelayanan pendampingan pastoral kepada jemaatnya. Program yang dibuat harus dipastikan dapat benar-benar mendarat dalam mengakomodir pelayanan pastoral secara holistik kepada jemaat. Model perkunjungan pastoral dirasa tidak efektif bila melihat jumlah jemaat yang sedemikian banyak. Salah satu pioneer dalam pengelolaan dan pendampingan pastoral megachurch adalah Yoido Full Gospel Church di Korea, yang digembalakan oleh Pastor Paul (David) Yonggi Cho.

\section{Menilik Model Pastoral Yoido Full Gospel Church}

Gereja Yoido Full Gospel merupakan sebuah gereja yang dirintis pada tahun 1958. Semula, gereja ini dikenal dengan gereja Sodaemun, karena letaknya yang berada di kota tersebut. Gereja ini memulai dengan 5 orang anggota jemaat. ${ }^{21}$ Awal mula pembentukan gereja hanya dimulai disebuah rumah kecil. Dua pendeta mula-mula mulai berjuang untuk memberikan pelayanan kepada orang-orang disekitarnya dengan cara door to door. Para perintis dengan gigih mulai memberikan pelayanan spiritual, membantu orang miskin dan memberikan layanan kemanusiaan bagi yang membutuhkan. Beberapa bulan kemudian, jumlah jemaatnya berkembang menjadi 50 orang.

Pendeta Yonggi Cho merupakan seorang pelopor dari pergerakan gereja Yoido di Korea.

\footnotetext{
${ }^{20}$ Krisetya, Teologi Pastoral, 39.

${ }^{21}$ M. Sukamto, Rahasia Keberhasilan Gereja di Korea, (Yogyakarta : Andi, 2006), 75.
} 
Pendeta Paul (David) Yongggi Cho lahir dari keluarga yang beragama Budha pada tahun 1936. Ia berpenyakit TBC pada masa muda, lalu beralih agama menjadi Kristen melalui doa dan kesaksian seorang pemudi Kristen yang menggunjunginya di rumah sakit. Sesudah tamat dari Institut Alkitab Sidang Jemaat Allah di Seoul, Cho mulai memulai mengadakan kebaktian di lapangan terbuka. Warna teologi kemakmuran yang dibawanya, dan pandangannya melalui Berkat Tiga Kali Lipat menjadi ciri khas dari Pendeta $\mathrm{Cho}^{22}$.

Kelompok-kelompok kecil yang dikembangkan oleh Pendeta Cho, akhirnya menjadi gereja dewasa yang bernama Yoido Full Gospel Church. Gereja ini terletak di pinggiran kota Seoul Korea. Beberapa waktu kemudian, setelah jemaat bertambah jumlahnya, gedung gereja yang ada tidak mampu menampung semua jemaatnya. Pada tanggal 6 April 1969 dimulai pembangunan gedung gereja di Yoido, yaitu sebuah kawasan yang terletak di jantung kota Seoul. Pembangunan ini selesai dan ditahbiskan pada tanggal 24 September 1973. Tepatnya pada tanggal 1 Januari 1984 nama gereja diubah menjadi gereja Yoido Full Gospel. ${ }^{23}$ Gedung baru yang dibangun di Yoido mampu menampung semua jemaat yang ada pada waktu itu.

Jumlah jemaat terus berkembang pesat seiring dengan berjalannya waktu. Salah satu penyebab dari pertumbuhan jemaat adalah dikenalnya pastor Yonggi Cho di seluruh penjuru Korea. Pada tahun 1980-an, Full Gospel Central Church memutuskan untuk mendirikan gereja-gereja satelit di seluruh kota Seoul. Gereja ini telah melihat jauh ke depan, karena jemaat akan bisa terus berkembang di seluruh kota Seoul. Tahun 1983, kursi auditorium telah diperluas untuk 12.000 jemaat. Tujuh minggu kemudian, jumlah tersebut tidak cukup untuk menampung seluruh anggota. Pertumbuhan terjadi de-

\footnotetext{
${ }^{22}$ Anne Ruck,Sejarah Gereja Asia, (Jakarta :

BPK Gunung Mulia, 2008), 310.

${ }^{23}$ M. Sukamto, Rahasia Keberhasilan Gereja di Korea,.. 75
}

ngan sangat cepat. Pada tahun 1992, anggota jemaat telah bertambah mencapai 700.000 orang. Melihat hal ini, kebutuhan untuk gereja-gereja satelit menjadi lebih mendesak. Gereja-gereja satelit merupakan pemasok anggota baru bagi gereja induk. Sel jaringan yang luas dibuat sedemikian rupa, guna mencapai pertumbuhan yang signifikan. Tahun 2003 keanggotaan berhasil mencapai 780.000jemaat. Pastor David Yonggi Cho telah mengambil keputusan untuk pensiun sebagai kepala pendeta beberapa kali, tetapi gereja mengalami konflik antar penatua, sehingga menyebabkan diaterjun kembali ke pelayanan gereja pada akhirtahun 2006. Hasilnya, tahun 2007 keanggotaan gereja mencapai 830.000 jemaat, dengan tujuh layanan ibadah Minggu yang diterjemahkan ke dalam16 bahasa.

Peledakan jumlah jemaat tersebut menarik perhatian dari skala nasional dan internasional. Guna mengakomodasi rasa ingin tahu banyak pihak,maka diadakan seminar-seminar berkaitan dengan rahasia keberhasilannya. Adapun beberapa kegiatan yang pernah diselenggarakan antara lain adalah

1. Bulan Maret 1973 diadakan acara the Osanri Prayer Mountain. Acara ini diadakan bagi orang-orang yang rindu untuk berdoa dan puasa secara korporat. Acara ini dihadiri oleh banyak orang dari berbagai penjuru dunia.

2. Bulan November 1976, Church Growth International. Acara ini didedikasikan untuk mengajarkan prinsip-prinsip serta pengorganisasian tentang penginjilan dan pertumbuhan gereja. Peserta dari acara ini adalah para pendeta yang ingin memperdalam tentang penginjilan dan pertumbuhan gereja.

3. World Evangelical Center, merupakan sebuah lembaga pendidikan untuk melengkapi gereja dalam bidang penginjilan. Lembaga ini mulai dibuka pada tanggal 20 Januari 1977.

4. Studio televisi dibuka pada tanggal 31 Desember 1981. Program televisi ini dibuat guna mendukung pelayanan ibadah dalam aras nasional maupun internasional.

5. The Full Gospel Educational Research Institute, sekarangberubah menjadi the Inter- 
national Theological Institute, yang berfungsi mendidik orang-orang untuk menginjil dan memberi pengetahuan teologia.

6. Bulan Januari 1986, didirikan Elim Welfare yaitu fasilitas untuk orang tua, kaum muda, tunawisma, dan pengangguran. Lembaga ini didirikan di bawah naungan gereja, dan merupakan pengembangan pelayanan dari gereja kepada jemaat serta masyarakat setempat. Lembaga ini juga memberikan pelatihan kerja dan kemudian memberikan pilihan tempat pekerjaan.

7. Pada bulan Maret tahun yang sama, gereja mendirikan Universitas Hansei. ${ }^{24}$

Program-program gereja di atas merupakan pengembangan dari pelayanan gereja kepada jemaat dan masyarakat. Kegiatan tersebut terus dikembangkan dan dikelola sampai pada masa kini. Setiap tahunnya, Pastor Cho tetap mengadakan konferensi yang dihadiri oleh para pendeta, aktifis, serta pakar pertumbuhan gereja untuk belajar bersama dalam hal pengelolaan dan pemberdayaan warga gereja.

Pastor Paul Yonggi Cho merupakan pendeta senior dari Yoido Full Gospel Church. Jemaat yang begitu banyak tidak dapat tertangani sendiri oleh pendeta senior. Oleh sebab itu, diperlukan tenaga bantu (pendeta pembantu) dalam melayani seluruh jemaat tersebut. Pastor Cho mengangkat 171 pendeta yang membantu pengelolaan pelayanan di gerejanya. Di samping itu, ada 356 pendeta yang ditempatkan di berbagai penjuru kota guna membantu pelayanan pastoral gereja. Pendeta-pendeta tersebut merupakan orang-orang yang ikut terlibat aktif dalam berbagai pelayanan di gereja. Adanya banyak orang yang terlibat dalam pelayanan, membuat ringan beban pelayanan pendeta senior.

Jemaat yang semakin berkembang menuntut perhatian lebih dari para pendeta. Oleh sebab itu, Pastor Cho membuat sebuah model pelayanan pastoral yang dikembangkan di gerejanya. Model pelayanan pastoral ini digunakan untuk memberi perhatian maksimal kepada setiap jemaatnya, sehingga

\footnotetext{
${ }^{24}$ ibid
}

setiap jemaat mendapatkan pelayanan pastoral secara holistik. Model yang dikembangkan adalah home cell. Home cell atau secara umum dikenal dengan istilah komsel (kelompok sel), merupakan sebuah model pelayanan pokok yang dikembangkan oleh Pastor Cho dan menjadi ciri khas dalam pelayanan di Yoido Full Gospel Church.

Home cell merupakan ujung tombak di gereja Yoido Full Gospel. Salah satu rahasia pertumbuhan jemaat yang semakin pesat adalah melalui home cell. Sergio E. Arevalo, Jr., dalam tulisannya menyatakan "the homecell is the main evangelistic method of the Yoido Full Gospel Central Church that's why it is grown to million." ${ }^{25}$ Pada dasarnya home cell dapat menarik orang untuk masuk ke dalam komunitasnya melalui gaya hidupnya, atau sering disebut dengan "penginjilan gaya hidup". Kelompok kecil ini bila difungsikan dengan benar, akan tampak seperti koinonia pada zaman para rasul. Pengalaman koinonia yang dialami oleh para anggotanya akan meluap keluar kepada orang-orang di sekitar lingkungannya. Hal inilah yang membuat orang yang melihat menjadi tertarik dan bergabung dengan komunitas tersebut.

Pastor Cho melukiskan ciri khas home cell yang dikembangkan di gerejanya dalam buku yang berjudul Successful Home cell Groups. Pada bagian buku itu Pastor Cho menuliskan

I like to describe Full Gospel Central Church as the smallest church in the world as well as the biggest church in the world. It is the biggest because, as of writing of the book, our congregation numbers more than 150.000 people. But it is also the smallest church in the world-because every member is part of a home cell group consisting of fiftteen families or fewer. ${ }^{26}$

${ }^{25}$ Cell System For Church GrowthDiunduh dari http://www.freewebs.com/drsergz/cell_system_for_church _growth.htm, 25 Mei 2011, pkl 20.30 WIB

${ }^{26}$ Paul Yonggi Cho, Successful Home cell Groups ( New Jersey : Logos International, 1981 ), 50 
Pastor Cho memberi gambaran bahwa setiap anggota dari gereja telah tergabung dalam home cell dan menjadi keluarga yang saling memperhatikan.

Pernyataan Pastor Cho di atas, secara implisit hendak menggambarkan bahwa pelayanan pastoral terjadi lewat home cell. Jemaat yang begitu besar akan menjadi kelompok-kelompok kecil, sehingga mempermudah pelayanan pastoral kepada jemaatnya. Melalui home cell" a person who comes into the cell group discovers he is an 'I' and not it". ${ }^{27}$ Seseorang akan mendapatkan keluarga baru dalam home cell. Keluarga inilah yang akan mendukung keberadaannya menjadi seorang pribadi yang utuh.

Keunikan lainnya dalam home cell yang dikembangkan oleh Pastor Cho adalah wanita yang dipercaya sebagai pemimpin sel. Di Korea, wanita dianggap sebagai kelas dua. Namun, di sistem sel yang dikembangkan oleh Pastor Cho, perempuan disetarakan dengan lelaki dan diberikan wewenang untuk memimpin sel. Ini didasari dari pengamatan Pastor Cho yang melihat bahwa banyak perempuan tidak ada aktifitas di siang hari. Alangkah baiknya bila pada siang hari diadakan pertemuan dari beberapa perempuan untuk bersekutu bersama dalam kelompok kecil dari lingkungan yang berdekatan. Embrio inilah yang selanjutnya melahirkan banyak kelompok kecil di dalam gereja yang digembalakan oleh Pastor Cho.

Melalui kelompok-kelompok kecil, jemaat akan mudah berinteraksi untuk saling membantu antar anggotanya. Dari sekian banyak kelompok kecil ini, Pastor Cho bertugas sebagai orang yang memberikan supervisi kepada para ketua wilayah, disertai dengan modul yang telah dibuat, untuk selanjutnya dapat disebarluaskan kepada tiap-tiap anggota sel. Oleh sebab itu, setiap wilayah mempunyai pemimpin yang akan meneruskan pesan dari gembala jemaat kepada seluruh jemaatnya lewat home cell, dan juga sebaliknya dari jemaat kepada gembalanya.

\footnotetext{
${ }^{27}$ Ibid, 51
}

Menurut Sutrisna, ada beberapa keunggulan kelompok kecil sebagai sarana pendampingan, yaitu:

a. Materi pembinaan dapat dengan mudah disesuaikan dengan kebutuhan dan tingkat pertumbuhan anggota-anggotanya yang cenderung homogen. Hal ini berbeda dengan materi acara persekutuan kelompok besar atau tema-tema khotbah di gereja, yang harus disajikan untuk memenuhi kebutuhan jemaat yang sangat beragam.

b. Suasana kelompok kecil lebih kondusif dan mendukung setiap anggotanya untuk aktif dalam berpartisipasi berdiskusi. Hal ini akan mendorong pemahaman yang lebih mendalam dan relevan. Para anggota juga lebih mudah terbuka kepada orang yang lebih sedikit, seperti mengajukan pertanyaan maupun pendapatnya. Pemimpin kelompok juga mendapat umpan balik dalam penyampaian firman Tuhan yang dua arah. Hal ini berbeda dengan kualitas pemahaman yang diperoleh dari sikap pasif dan satu arah dalam mendengar khotbah dalam kelompok besar.

c. Jumlah anggota yang lebih sedikit dalam kelompok kecil akan memungkinkan pemimpin kelompok untuk memberikan dukungan doa, perhatian, dorongan, nasihat, ataupun teguran yang bersifat pribadi. Hal ini akan sangat sulit dilakukan dalam kelompok besar.

d. Dalam suatu kelompok kecil, seseorang lebih mudah untuk saling berbagi, saling memperhatikan, saling mendorong dan mendukung, saling mengasah, dan saling bertumbuh dalam kebenaran. Misalnya, seorang anggota kelompok terdorong untuk lebih setia melakukan saat teduh ketika dia mendengar rekan kelompoknya yang sangat sibuk mau berjerih payah untuk bangun pagi untuk bersaat teduh. Atau dua orang yang memiliki karakter yang berbeda belajar saling menerima selama mereka berada dalam kelompok tersebut. ${ }^{28}$

Senada dengan pendapat Sutrisna, sistem home cell yang dikembangkan di gereja Pastor Cho juga hendak menciptakan jemaatnya untuk bertum-

${ }^{28}$ Sutrisna, Visi Pemuridan (Bandung: Literatur Perkantas, 2006 ), 31-32. 
buh mencapai eksistensi dirinya secara maksimal. Di samping itu, home cell merupakan kepanjangan tangan seorang pendeta dalam hal pelayanan pastoral. Secara spiritual, home cell dirancang untuk melatih semua orang percaya (jemaat), untuk dapat berfungsi dalam kapasitas mereka sepenuhnya di dalam tubuh Kristus. Setiap orang diharapkan untuk menemukan dan mengembangkan karunia rohaninya, dan menggunakannya dalam pelayanan untuk memperkuat tubuh Kristus (gereja).

Di dalam kelompok kecil ini, setiap anggota dapat menggali potensi dalam dirinya untuk dapat berfungsi dalam pelayanan gerejawi. Dari segi sosial, melalui home cell kebutuhan dan perhatian dalam seluruh aspek hidup jemaat dapat tertangani dengan baik oleh sesama anggotanya. Antar anggota home cell akan lebih mudah memperhatikan dan membantu kebutuhan sesamanya dari berbagai bidang kehidupannya. Interaksi yang baik antar anggota akan memunculkan suasana yang kondusif dalam membangun kemitraan jemaat. Kebutuhan jasmani, ekonomi, sampai masalah pekerjaan dan pendidikan pun akan dapat terdeteksi sedini mungkin, guna mencari solusi yang tepat dalam penanganannya. Sesama anggota home cell akan merasa lebih dekat, sampai merasa seperti keluarga sendiri. Perhatian inilah yang menjadi keunggulan dari home cell di Yoido Full Gospel Church. Model inilah yang dikembangkan oleh Pastor Cho dalam upaya melakukan pelayanan pastoral secara holistik kepada jemaat yang sangat banyak, melalui kepanjangan tangan sistem home cell. Jemaat yang sedemikian banyak ini dapat tertangani dengan baik dalam wadah home cell di berbagai bidang kehidupannya.

\section{Usulan Konseptual Pembinaan Warga Gereja}

Perspektif Clinebell dalam pendampingan pastoral menekankan pada pembebasan dan pertumbuhan. Melalui pendampingan pastoral yang dilakukan oleh gereja, jemaat dapat menemukan keutuhan di dalam kehidupannya. Untuk mencapai keutuhannya, diperlukan sinergi di setiap elemen dalam ge- reja. Yang menjadi titik tolak dalam konsep Clinebell adalah aspek spiritual menjadi kunci dari pertumbuhan kehidupan manusia.

Konsep Clinebell yang menggembangkan aspek spiritual dalam mencapai pertumbuhan menuju keutuhan kehidupan manusia, perlu selaras dengan pembinaan warga gereja. Aspek spiritual menjadi fokus pendampingan pastoral bagi jemaatnya. Pandangan teologis dari gereja menjadi landasan dari perhatian gereja terhadap aspek spiritual. Hampir seluruh kegiatan yang diadakan oleh gereja bermuatan spiritual. Hal ini disebabkan oleh landasan firman Tuhan sebagai dasar bergereja yang diyakini sebagai penggerak di dalam gereja, sehingga kehidupan spiritual dijadikan sebagai pondasi dari kehidupan gereja dan jemaatnya.

Para pihak yang terlibat dalam pembinaan warga gereja, perlu diselaraskan supaya berpandangan bahwa kehidupan spiritual merupakan titik tolak kehidupan yang sebenarnya. Konsep yang perlu dikembangkan yaitu apabila jemaat mempunyai kehidupan spiritual baik, maka masalah-masalah hidupnya dapat teratasi dengan baik pula. Dimensi spiritual menjadi dasar untuk mengembangkan aspek yang lain di dalam kehidupan jemaat. Paradigma inilah yang dikembangkan di dalam kehidupan jemaat di dalam bergereja. Oleh sebab itu, pendampingan pastoral yang diusulkan Clinebell lebih menitikberatkan pada bidang spiritualnya sebagai pusat kehidupan holistik manusia.

Clinebell lebih menitikberatkan pada pendampingan spiritual tiap-tiap individu, namun acapkali yang terjadi di gereja pada umumnya pendampingan spiritual dilakukan secara korporat atau berjemaat. Pendampingan spiritual di gereja umumnya dilakukan melalui berbagai kegiatan ibadah gerejani. Hal yang terlupakan dalam pendampingan pastoral di dalam gereja adalah pendampingan pastoral secara individu. Sistem dan mekanisme penatalayanan dalam gereja perlu diselaraskan dengan kuantitas jemaat yang ada, sehingga kebutuhan pendampingan pastoral individu dapat terlayani secara merata. 
Pendampingan pastoral secara universal atau berjemaat tidak sepenuhnya dapat menjawab dan menjadi solusi bagi kebutuhan warga gereja.Ini dikarenakan tingkat spiritual warga gereja yang beragam, sehingga pendampingan pastoral secara spiritual tidak dapat diseragamkan. Bagi warga gereja yang mempunyai tingkat spiritual tinggi tidak akan mengalami kesulitan dalam pembimbingan kerohaniannya. Namun, apabila ada warga gereja yang masih dalam taraf belajar berspiritual, maka diperlukan waktu intensif dan pendampingan secara individu dalam penanganannya. Oleh sebab itu, gereja perlu mengembangkan pendampingan pastoral secara individu melalui pengaktifan dan pelatihan pemimpin dan tim pembinaan warga gereja secara signifikan, guna pencapaian keutuhan di dalam diri jemaat. Dalam perspektif Clinebell, spiritual menjadi pusat kehidupan manusia, apabila kebutuhan spiritual di dalam jemaat terlayani dengan baik, maka kehidupan secara holistik dapat pula terlayani dengan baik.

Berbeda dengan Clinebell, Wiryasaputra memberikan perspektif yang berbeda berkaitan pendampingan pastoral holistik kepada jemaat. Wiryasaputra mencoba memformulasikan keberagaman aspek hidup manusia ke dalam empat hal, yaitu aspek fisik, mental, spiritual dan sosial. Keempat aspek tersebut di atas saling berkaitan satu dengan yang lain, serta saling mempengaruhi secara sistemik dan sinergik membentuk eksistensi manusia sebagai keutuhan dan bertumbuh kepada aktualiasasi dirinya. Oleh sebab itu, empat aspek dalam diri manusia tersebut harus mendapatkan penanganan secara proporsional, guna menciptakan keutuhan.

\section{Alternatif Solusi Pendampingan Pastoral Holistik}

Dalam kerangka konseptual yang disajikan oleh Clinebell, ia menitikberatkan bahwa spiritual menjadi pusat dari kehidupan. Spiritual perlu dirawat untuk dijadikan sebagai titik tolak pengembangan manusia secara utuh. Wiryasaputra lebih lanjut menegaskan tentang integrasi antara empat aspek dalam hidup manusia, yaitu spiritual, sosial, mental dan fisik. Konsep Clinebell yang selama ini digunakan oleh gereja pada umumnya, yaitu memusatkan pada spiritual. Wiryasaputra memberi penjelasan terkait dengan integrasi antara keempat aspek manusia yang tidak dapat dihindarkan. Apa yang dikerjakan Yonggi Cho memberikan sebuah model untuk tetap memusatkan kepada spiritual, dan dapat mengintegrasikan keempat aspek tersebut. Model yang dikembangkan oleh Cho, dapat dijadikan sebagai sebuah usulan pendampingan pastoral holistik di gereja Indonesia.

Model pendampingan pastoral yang dikembangkan di Yoido Full Gospel Church dapat dijadikan sebagai sebuah alternatif solusi di pembinaan warga gereja. Adapun beberapa usulan program gereja yang dapat dikembangkan dalam kerangka pendampingan pastoral holistik adalah

\section{Kelompok Kecil}

Kelompok kecil menjadi model andalan untuk dapat mendampingi jemaat secara personal dan proporsional. Gereja di Korea memakai istilah Home cell sebagai sebutan untuk kelompok kecilnya, sedangkan banyak gereja di Indonesia banyak menyebutkan dengan kelompok sel. Model ini dijadikan sebagai kepanjangan tangan dari pendeta senior dalam memperhatikan dan mendampingi jemaatnya di dalam realitas kehidupannya. Apa yang menjadi isi hati dari pendeta senior akan segera diteruskan oleh tim pembinaan warga gereja kepada seluruh jemaatnya lewat kelompok sel. Demikian juga sebaliknya, permasalahan atau uneg-uneg yang ada di kalangan jemaat akan disalurkan kepada pendeta seniornya.

Melalui model kelompok kecil ini, pendeta senior dan tim pembinaan warga gereja dapat bersinergi untuk mendampingi jemaatnya secara holistik. Model ini dikembangkan berdasarkan dari heterogenitas jemaatnya. Kelompok sel ini dikembangkan mengingat jumlah jemaat yang begitu banyak, penyebaran jemaat yang begitu luas, disertai dengan kompleksitas yang ada di dalam jemaat. Oleh sebab itu, model kelompok kecil menjadi efektif sebagai 
model pendampingan pastoral holistik di dalam gereja.

\section{Pemberdayaan Kaum Perempuan}

Di Yoido Full Gospel Church, kaum perempuan diberdayakan untuk dapat memimpin kelompok-kelompok kecil. Stratifikasi gender ditiadakan demi mendampingi jemaatnya secara efektif dan menyeluruh. Kaum perempuan juga dilibatkan secara aktif dalam pendampingan pastoral kepada jemaat. Kefektifan dan keseriusan kaum perempuan dalam melayani dijadikan sebagai sebuah alasan untuk melibatkan mereka dalam pelayanan pendampingan pastoral. Hal lain yang dijadikan sebagai dasar pelibatan kaum perempuan adalah aktifitas kaum pria yang begitu padat, sehingga agak sulit dalam pengaturan waktunya. Keterlibatan kaum perempuan menjadikan sebuah langkah positif untuk dapat menggerakkan semua elemen turut terlibat di dalam pembinaan warga gereja secara holistik.

\section{Pemberdayaan Kaum Awam}

Yoido Full Gospel Church Korea memberdayakan kaum awam untuk dapat membantu pelayanan pendampingan pastoral kepada seluruh jemaatnya. Bagi jemaat yang mempunyai keinginan dan mempunyai beban untuk terlibat dalam pendampingan pastoral, mereka akan dilatih untuk menjadi tim pembinaan warga gereja. Tim Pembinaan Warga Gereja merekrut orang-orang yang terpanggil dari kaum awam untuk diperlengkapi dengan pengetahuan dan skill pastoral, sehingga mereka dapat terlibat di dalam pelayanan pendampingan kepada jemaat.

Pemberdayaan kaum awam dilakukan sebagai upaya untuk dapat melayani jemaat yang sedemikian banyak, guna mencapai hasil yang maksimal. Kaum awam tersebut untuk kemudian diperlengkapi dengan skill dan pengetahuan berkaitan dengan pendampingan pastoral, pembinaan warga gereja melalui pelatihan-pelatihan singkat. Oleh sebab itu, gereja perlu membuka diri untuk melibatkan banyak kaum awam sebagai kepanjangan tangan pemimpin gereja.

Model kelompok kecil yang dikembangkan sebagai sarana pendampingan pastoral, dipimpin oleh seorang ketua sel. Guna membekali para ketua sel yang merupakan kaum awam tersebut, tim pastoral membekali dengan pelatihan singkat berkaitan dengan pendampingan pastoral. Namun, untuk dapat mengikuti pelatihan tersebut, calon peserta pelatihan harus telah mengantongi rekomendasi dari pemimpin yang ada di atasnya. Rekomendasi ini diperoleh berdasarkan pengamatan pola kehidupannya dan perkembangan imannya.

Pelatihan singkat ini dilakukan selama kurang lebih 1 - 2 bulan, dengan agihan waktu satu kali pertemuan setiap mingggunya. Dalam pelatihan tersebut, para calon pendamping pastoral jemaat diberikan pengetahuan tentang Alkitab terutama berkenaan dengan dogma dan dasar iman gerejawi. Di samping itu, diberikan pula materi tentang prinsip kepemimpinan kristen sebagai bekal memimpin para jemaat yang ada. Para calon pendamping jemaat juga ditraining tentang teori dan praktik mengkonseling jemaat, dan membinan iman jemaat. Para ketua sel inilah yang selanjutnya bertugas sebagai kepanjangan pembinaan warga gereja. Hal ini biasa dikenal dengan sebutan dari jemaat untuk jemaat. Adanya para ketua sel yang merupakan kaum awam dalam bidang pastoral, gereja dapat terbantu dalam pembinaan warganya dengan efektif dan efisien. Di samping itu, sense of belonging akan gereja dapat dimiliki oleh mayoritas jemaatnya.

\section{Pendampingan Kehidupan}

Pastor Cho mengajarkan kepada seluruh orang yang terlibat dalam pendampingan pastoral, untuk mendampingi jemaat dalam seluruh aspek kehidupannya. Pendamping pastoral yang bertugas di seluruh kelompok kecil, dengan siap sedia membantu jemaat dalam berbagai masalah di dalam realitas kehidupannya. Setiap jemaat juga diajarkan untuk saling tolong menolong antar sesamanya. 
Pendampingan dalam kehidupan antar anggota jemaat merupakan sebuah sarana untuk menjembatani perbedaan tingkat pendidikan, sosial dan ekonomi dalam jemaat. Orang yang berpendidikan rendah dapat di up grade oleh orang yang berpendidikan di atasnya. Oleh sebab itu, pergaulan dijadikan sebagai proses pendampingan kehidupan antar jemaat. Prinsip saling menolong inilah yang dikembangkan di kalangan warga gereja, yang dipelopori dan dikondisikan oleh pihak gereja.

Refleksi dari prinsip tersebut dapat diimplikasikan melalui para pembina warga gereja terlebih dahulu. Para pembina warga gereja diajarkan untuk mengasihi sesama seperti dirinya sendiri. Rasa kasih tersebut yang mendasari dalam praktik pendampingan pastoral kepada jemaat. Apabila pembina warga gereja mempunyai rasa kasih, maka jemaat yang didampingi pun akan merasa nyaman dan terbantu dalam kehidupannya sehari-hari.

Pendampingan kehidupan dilakukan dengan cara penanaman nilai-nilai spiritual dalam kehidupan. Selain itu, pendampingan juga dilakukan ketika jemaat sedang menghadapi permasalahan di dalam kehidupannya, baik ekonomi, pendidikan dan pekerjaan. Gereja, yang dalam praktiknya diwakili oleh para pendamping pastoral berusaha memberikan pelayanan yang terbaik serta memberikan solusi berkenaan dengan apa yang dibutuhkan oleh jemaat. Bagi yang kekurangan ekonomi, gereja siap sedia membantu melalui pasar murah, sembako gratis dan lain-lain. Di samping itu, bagi jemaat tidak mampu melanjutkan sekolah, gereja dengan siap sedia membantu memberikan beasiswa pendidikan. Jemaat yang tidak mempunyai pekerjaan pun, gereja berusaha menyediakan lapangan pekerjaan dan disertai dengan pelatihan keterampilan, guna meningkatkan skill mereka. Apabila sinergi di dalam jemaat terjadi secara komprehensif, maka jemaat dapat terlayani dengan holistik.

Pada dasarnya, model pendampingan pastoral yang dikembangkan oleh Yoido Full Gospel Church di Korea, dapat dijadikan sebagai alternatif solusi model pembinaan warga gereja secara holistik. Model kelompok kecil menjadi ciri khas, guna melakukan pendampingan yang bersifat holistik. Seorang pendeta yang tidak dapat terlibat aktif secara langsung dalam pendampingan pastoral, dapat terbantu dengan adanya kelompok kecil di jemaat. Model kelompok kecil sangat membantu pendeta untuk dapat menjalankan fungsi pembinaan kepada warganya.

\section{KESIMPULAN}

Gereja yang kuat terbentuk dari jemaat yang kuat. Jemaat yang kuat didapat dari pembinaan warganya yang secara aktif menyentuh keseluruhan kehidupan warga gerejanya. Gereja perlu berusaha mengembangkan pendampingan pastoral holistik kepada jemaatnya. Beragam program perlu dibuat dan dikembangkan untuk mencapai sebuah pendampingan pastoral holistik. Jemaat yang sangat banyak disertai permasalahan yang kompleks, mengharuskan para pembina warga gereja untuk mengatur strategi dan menyusun model, supaya dapat memberikan pelayanan pendampingan pastoral holistik kepada warga gerejanya.

Dalam rangka melakukan pendampingan pastoral, model kelompok kecil dapat dipakai sebagai alternatif sarana memberikan layanan pembinaan secara maksimal kepada warganya. Jemaat yang banyak dan beragam mengharuskan gereja membaginya ke dalam kelompok-kelompok kecil. Oleh karena itu, model ini dipakai sebagai sarana guna mengerti kebutuhan di dalam jemaat. Di dalam kelompok kecil, jemaat dapat saling berbagi dan berinteraksi dengan jemaat yang lain. Komunitas tersebut dipakai juga sebagai sarana untuk menyampaikan uneg-unegnya, baik berkaitan masalah pribadi maupun masalah gereja. Model pendampingan pastoral ini cukup efektif untuk dikembangkan di gereja, karena jemaat yang sedemikian banyak mendapat perhatian dengan baik.

Keefektifan dalam pelayanan pastoral kepada jemaat merupakan salah satu keunggulan dari 
model pembinaan kelompok kecil. Jumlah yang relatif kecil memungkinkan untuk dapat mendampingi jemaat secara lebih intensif, sehingga kebutuhankebutuhan warga gereja dapat terakomodir dengan baik. Kaderisasi dan pelatihan yang tepat merupakan kunci untuk mengembangkan model kelompok kecil sebagai pembinaan warga gereja.

Pemberdayaan kaum awam menjadi salah satu penunjang keberadaan model pembinaan dengan kelompok kecil. Kaum awam yang diperlengkapi, untuk kemudian dapat diberdayakan menjadi salah satu penolong gereja dalam membina warganya. Dalam upaya memberdayakan tersebut, kaum awam perlu dibekali dengan pelatihan dan pembe-

\section{DAFTAR RUJUKAN}

Badudu, Zain. Kamus Besar Bahasa Indonesia. Jakarta: Pustaka Sinar Harapan, 1994.

Cho, Paul Yonggi. Successful Home cell Groups. New Jersey : Logos International, 1981.

Clebsch, William A. \& Charles R. Jaekle. Pastoral Carein Historical Perspective.USA: Aronson, 1964.

Clinebell, Howard, ed., \& Anne Homes. Tipe-Tipe Dasar Pendampingan dan Konseling Pastoral. Yogyakarta: Kanisius, 2002.

Clinebell, Howard.Growth Counseling. Nashville: Abingdon, 1982.

Evans, C.F., "Peace." A Theological Word Book of the Bible. 1950.

Holistic Life, Diunduh dari http://www.fica.org/ ficalist/fica/live/holistik, Selasa, 23 Agustus 2015, 15.15 WIB.

Krisetya, Mesakh. Diktat Teologi Pastoral. Salatiga: Fakultas Teologi UKSW, 2006. kalan, guna memperlengkapi dengan keahlian dan kemampuan dalam membina warga jemaat. Pembidikan dan pendidikan yang tepat, menjadi kunci dalam menggerakkan kelompok kecil bertumbuh dan berkembang di dalam kerangka pembinaan warga jemaat. Apabila kelompok kecil dapat digerakkan, maka pembinaan warga jemaat akan dapat berlangsung secara efektif dan efisien, untuk kemudian menuju ke arah pendampingan pastoral yang holistik. Di mana jemaat diperhatikan secara utuh oleh gereja, baik dari sisi spiritual, sosial, fisik dan mentalnya. Jemaat yang dibina secara holistik, akan berdampak pada gereja yang kuat dan sehat.

Ruck, Anne., Sejarah Gereja Asia, Jakarta: BPK Gunung Mulia, 2008.

Sukamto, M., Rahasia Keberhasilan Gereja di Korea. Yogyakarta : Andi, 2006.

Sutrisna, Visi Pemuridan. Bandung: Litratur Perkantas, 2006.

van Beek, Art. Pendampingan Pastoral. Jakarta: BPK Gunung Mulia, 2003.

van Rensburg, J. Janse, 2010, “A holistic approach to pastoral care and poverty," Verbum et Ecclesia 31(1), Art. \#386, 7 pages. DOI: 10.4102/ ve.v31i1.386. Education Research Complete, EBSCO host (accessed March 11, 2011).

Wiryasaputra, Totok Sumartho. The Social Responsibility Of Pastoral Care Ministry At The Hospital Setting In Indonesia, Master Thesis, Columbia Theological Seminary. 